\title{
Том \\ Visitor profiling at the Museum of Human Evolution of Burgos (Spain)
}

\section{María Eugenia Conforti, María Gabriela Chaparro, Pamela Degele and Juan Carlos Díez Fernández Lomana}

\begin{abstract}
This paper presents the first study ever conducted on the profile of visitors to the Museum of Human Evolution of Burgos (Spain), which exhibits the finds of the Atapuerca archaeo-paleontological sites. The research was guided by the principles of public communication of science and the methodology of the studies on museum visitors. The analysis reveals a positive perception; the Museum is associated with the sites and they are valued as cultural heritage. Complaints are very limited but useful to produce a set of recommendations to further improve the exhibition. In addition, the findings are placed in the context of similar research carried out at other museums in Spain.
\end{abstract}

Keywords

DOI

Introduction
Informal learning; Science centres and museums

https://doi.org/10.22323/2.17040203
Interpreting any site with a heritage value entails a constant challenge that requires continuous research, training and evaluation [ICOMOS, 2007]. As such, the case of the archaeo-paleontological sites of Atapuerca (Burgos, Spain) - which are unique for the extraordinary nature of their scientific discoveries - constitutes a clear example in order to study how a world heritage site is perceived by the people who attend a museum exhibition. It should be noted that the Museum of Human Evolution (hereinafter the MEH, from the Spanish Museo de la Evolución Humana) of the city of Burgos is the institution that the cultural management bodies of the Junta de Castilla y León decided to create in 2010 to house the Atapuerca scientific collection and present it to the general public. In this regard, it is possible to say that the two pillars on which any museum institution is built are the heritage it enshrines and its visitors. Thus, this paper aims to present and analyze the findings of a study conducted in 2015 on the audience of the museum, focusing on its permanent exhibition. The objectives of this research include gathering information on the MEH visitors and investigating the relationship they establish with scientific knowledge and the Atapuerca archaeological-paleontological heritage, in order to contribute food for thought to the debate on the importance of the study on the audience of archaeology museums in Spain. 
In particular, the questions raised include: who are the MEH visitors? Does the museographic message generate interest in the evolution and the role that Atapuerca plays in it, and does it promote greater awareness on the importance of the sites in the evolutionary process? Does the MEH meet the objective of connecting the archaeological sites with the exhibition? The technique adopted for such analysis is a survey that investigates the visitors' social demographic profile, habits, feedback, interests and opinions. Therefore, this work constitutes the first study on $\mathrm{MEH}$ visitors ever conducted by a group of researchers outside the institution, representatives of the Universidad de Burgos (Spain) and the Universidad Nacional del Centro de la Provincia de Buenos Aires (Argentina). ${ }^{1}$ However, it is necessary to point out that the museum previously carried out an unpublished internal study to gain insight on its audience, which was consulted by us at the time of the on-field survey [Museo de la Evolución Humana, 2013].

In order to fully grasp this case study, this papers starts with a detailed presentation of the MEH and its connection with the Atapuerca sites, to then describe the conceptual (public communication of science) and methodological (museum visitors profiling) framework of our work and, finally, to present and discuss our main findings.

\section{Museo de la Evolución Humana (Museum of Human Evolution)}

\section{The Sierra de Atapuerca, the scientific knowledge generated and its management}

The Sierra de Atapuerca (Figure 1) hosts a number of archaeo-paleontological sites that make it possible to complete the complex evolutionary tree for the past million years in Europe. "Atapuerca is key to learn about the past, as it hosts remains of $H$. antecessor, heidelbergensis and sapiens. Thanks to the studies carried out at the site, it was possible to hypothesize the African origin of the former, and its role as a link for later species, the neandertalization of $\mathrm{H}$. heidelbergensis and the divergence of our species" [Díez Fernández-Lomana et al., 2011, p. 211]. Its importance can be appreciated thanks to countless high-level scientific publications (in Nature, Science, Journal of Human Evolution, etc.), the appearance of science popularization books [Arsuaga and Martínez, 2001; Carbonell and Sala, 2000] or the acknowledgments of its value in terms of heritage: the classification as a Property of Cultural Interest in the Archaeological Area category (1991), the subsequent classification as a cultural space by the Junta de Castilla y León (2007), and the inscription in the list of UNESCO World Heritage sites (2000).

The Junta de Castilla y León develops important promotion initiatives and carries out a wide array of actions aimed at the preservation and protection of the sites, research and public dissemination. In 2009, the Junta established the "Sistema Atapuerca. Cultura de la Evolución" (hereinafter SACE) with the objective of valuing, benefiting from and enriching the resources Atapuerca is comprised of (sites, archaeological park, visitor reception centres, Centro Nacional de Investigación de la Evolución Humana and Museum of Human Evolution), transforming public space and revitalizing the urban area of Burgos (Figure 2).

\footnotetext{
${ }^{1}$ This study is independent of the Museum of Human Evolution and is part of a larger research project entitled Public Communication of Archaeology and Archaeological Heritage, funded by the European Economic Community in the framework of an Erasmus postdoctoral grant for Latin American professionals and implemented by María Eugenia Conforti at Universidad de Burgos between 2014 and 2015 [Conforti et al., 2015; Conforti et al., 2017a; Conforti et al., 2017b].
} 


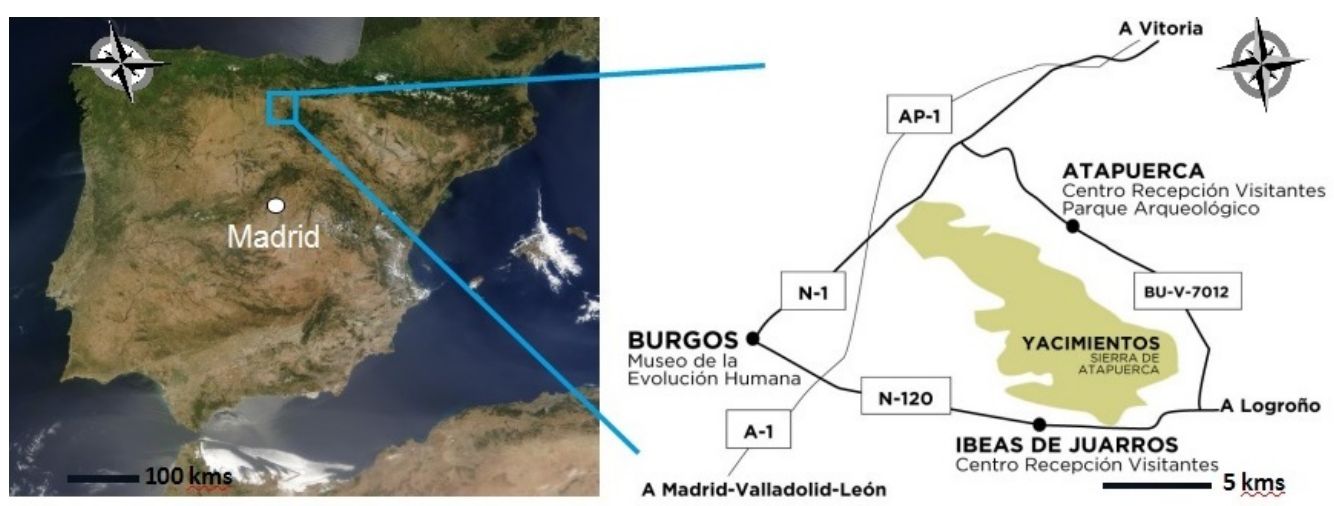

Figure 1. Map showing the location of Atapuerca.

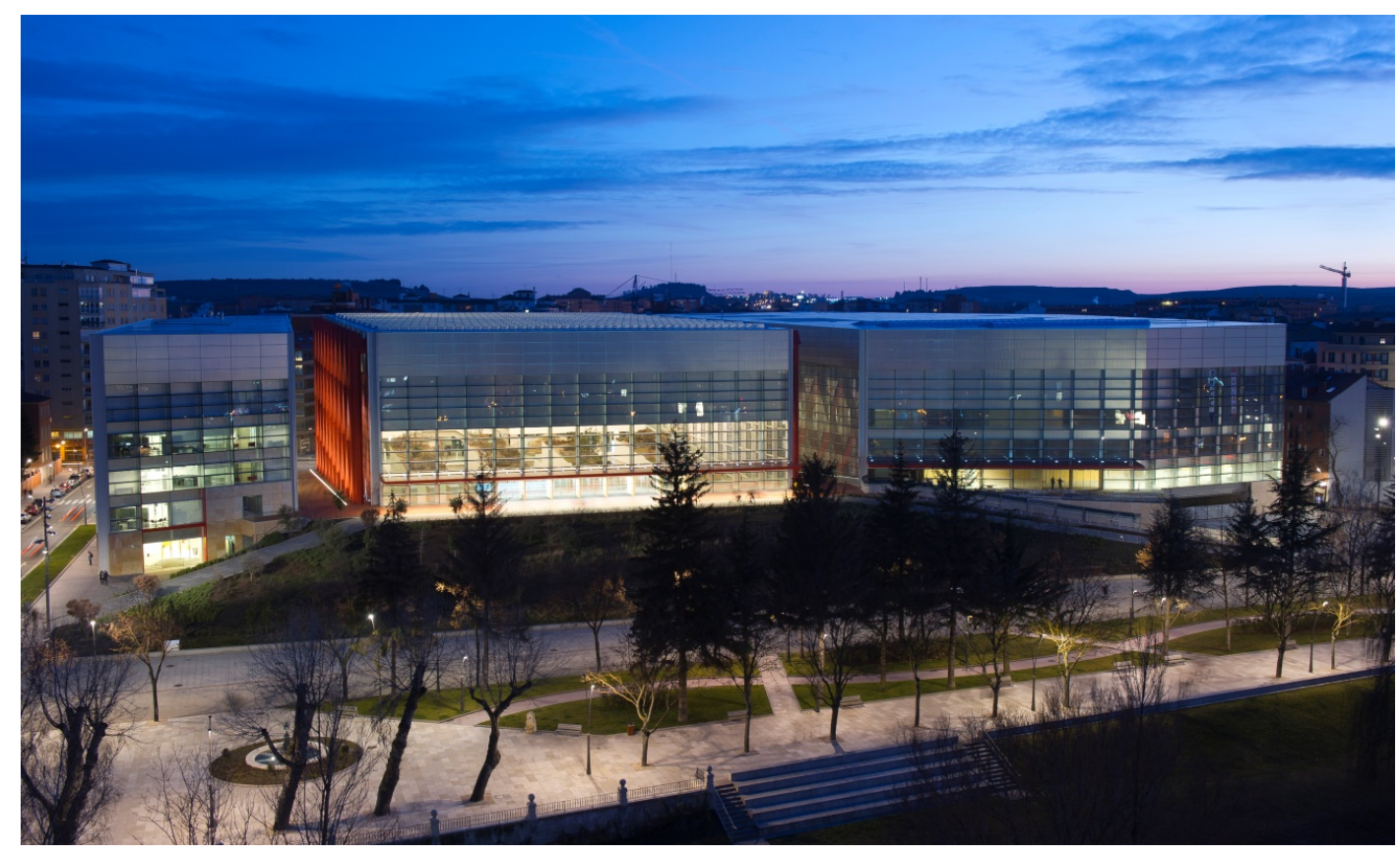

Figure 2. External view of the MEH building. Source: MEH.

The Decree on the establishment of the MEH details its objectives [Comunidad de Castilla y León, 2009, p. 2]:

"Contribute to the protection, conservation and dissemination of the archaeological, paleontological, historical and cultural heritage, especially in relation to the archaeo-paleontological sites of the Sierra de Atapuerca; study, valorize and disseminate the archaeological, paleontological, historical and cultural heritage of Castile and León, particularly in relation to human evolution (...); establish cooperation and collaboration relations with other centres (...) promoting the popularization and knowledge of Atapuerca (...), as well as advances in the research on human evolution; use scientific precision, as well as attractive, accessible and didactic tools to provide visitors with the fundamentals on the human evolutionary process with regard to its biological, ecological and cultural elements, including the sites of $(\ldots)$ Atapuerca; and become a social, cultural and economic reference within the Community of Castile and León, and a flagship facility in relation to the scientific debate and the respect for the environment." 
The MEH was inaugurated in July 2010 and has a surface comprising 15 thousand square metres: it is 60 metres long, 90 metres wide and 25 metres high, being divided into four floors:

Floor -1: dedicated to the sites of Atapuerca, it consists of four large prismatic sections containing fossils and original pieces, among which the human remains of Homo antecessor and Homo heidelbergensis stand out. The separation of these modules is meant to imitate the open trenches in the Sierra de Atapuerca, showing the changing vegetation that existed at different stages of the past. Light plays an important role, obscuring the finds from the interior of the caves and illuminating the history of the sierra and the research projects or finds from recent prehistory. This first floor is completed by resources focusing on information about the research team and their working methods. In addition, there are plenty of audiovisual and infographic resources (Figure 3).

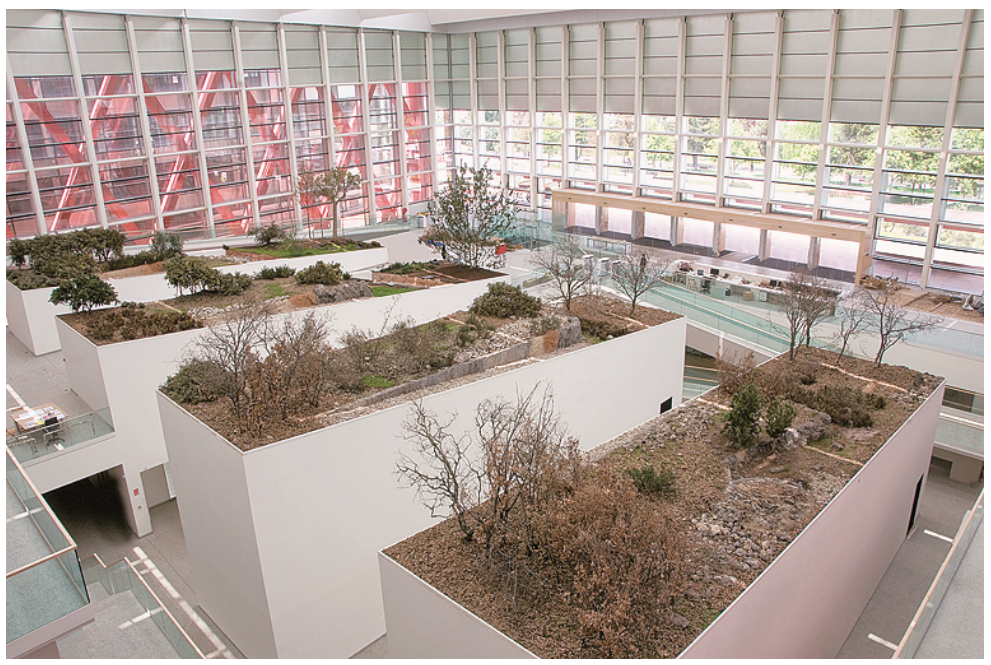

Figure 3. General interior view of the MEH. Floor 1. Source: Luís Mena.

Floor 0: it focuses on the "Biological Evolution" of human beings, narrating the origin of the theory of evolution through Darwin and the journey of the Beagle. The biological characteristics of living beings, vertebrates and primates are explained, as well as the anatomical changes throughout the history of life. The study of the brain stands out, by means of a large sculpture that contains several videos and drawings. At the centre of the large hall is the "Hominid Gallery," a circular space framed by copies of human fossils from all periods and continents, which contain ten hyper-realistic sculptures, generating a 360-degree view of evolution, including reproductions, among others, of the most emblematic hominids of Atapuerca (Figure 4).

Floor 1: it is devoted to "Cultural Evolution" over the past three million years. Art, fire and technology are the leading themes, whereas a space of the hall is intended to show the so-called "Neolithic revolution," a process dating back to about ten thousand years ago, in which the egalitarian economy of hunter-gatherers gave way to agro-pastoral subsistence, in which plants and 


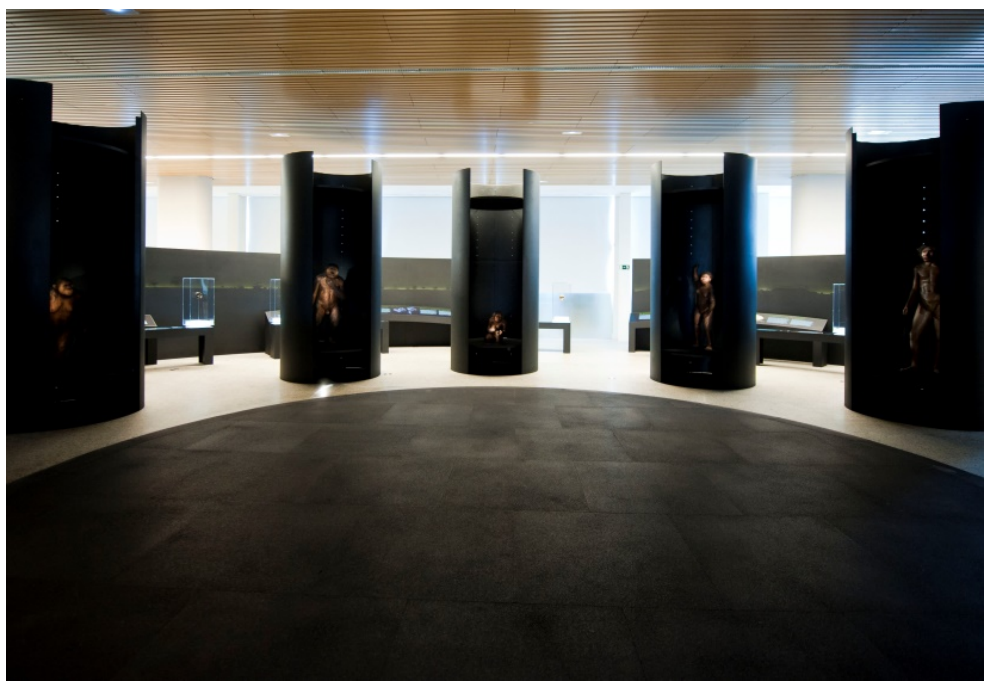

Figure 4. Hominid Gallery on "Floor 0: Biologic Evolution". Source: MEH.

animals were domesticated, and private property was created. An array of videos and objects are intended to show the steps of technological evolution such as stone carving, items made with wood, bones and baked clay. The interior of a large metallic structure hosts audiovisual materials on the importance of fire for human beings and the evolution in its use. Several displays focus on the behaviour of humans in relation to death, exhibiting models that recreate the ways $H$. sapiens and Neanderthals used to live at different archaeological sites. In addition, videos are projected onto large stone wall reproductions that allow visitors to contemplate the Palaeolithic art of European caverns (Figure 5).

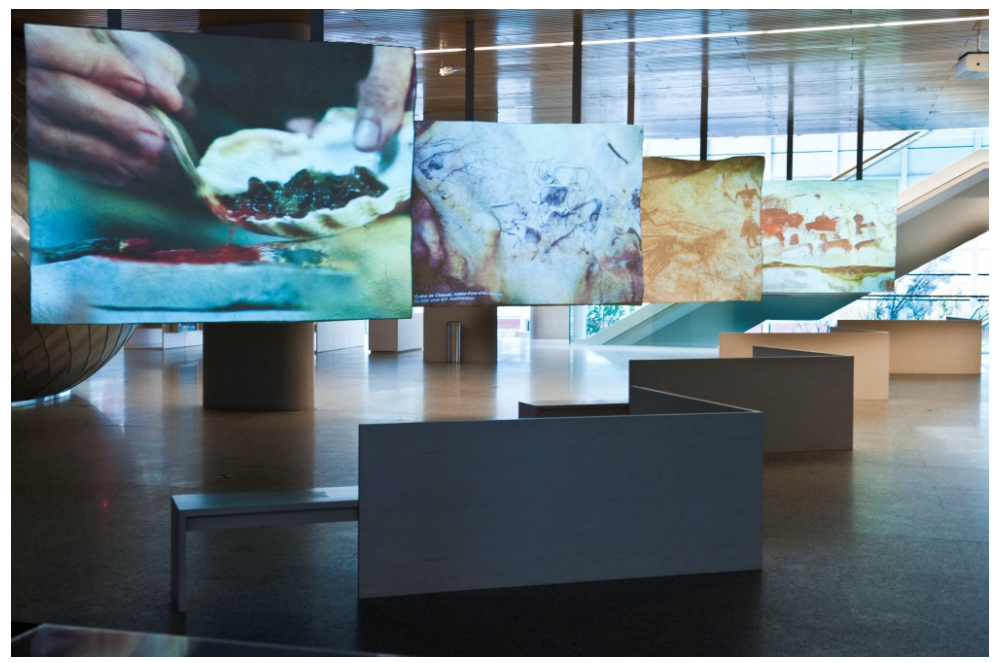

Figure 5. Walls with cave paintings on "Floor 1: Cultural Evolution". Source: MEH.

Floor 2: it is devoted to ecosystems. There, you can admire the landscape of the Sierra de Atapuerca over the past million years, whereas the audiovisual material describes the main ecosystems of hominids (rainforest), early humans (savannah), the occupation of Eurasia (woodland) and the planetary colonization (steppe-tundra). Finally, this floor hosts a bookstore and a soda machine, with a recreation area as well. 
The initial period of the Sistema Atapuerca Cultura de la Evolución was impressive, with more than 600,000 visits over the first two years, of which the MEH accounts for $60 \%$ [Alonso Alcalde and Martín Nájera, 2013]. According to estimations, in the summer of 2016 it reached 2.5 million visitors, with an economic impact of at least 40 million euros per year, $26 \%$ more than before the opening of the MEH [Ortega Azabache, 2016]. In this sense, the studies on tourist attractions place the $\mathrm{MEH}$ very close to the medieval cathedral of the city as a point of interest for visitors and to the archaeological sites as a main tourist destination of the province: the $\mathrm{MEH}$ was born because of the existence of the sites, which provide a basis for its whole architecture and content [Alonso Alcalde and Martín Nájera, 2013]. The current Scientific Director of the MEH is one of the directors of the Atapuerca excavations. In addition, the museum staff, including guides and coordinators, participated in these investigations. The aforementioned decree establishing the SACE also appointed the $\mathrm{MEH}$ as a lead partner of the system, which has to define the tourism policy to be implemented and the exhibitions to take place within the network, as well as in the Centros de Interpretación of the towns in the surroundings of the mountain range (Ibeas de Juarros and Atapuerca).

\section{Studies on museum audiences as a tool for the evaluation of science communication}

This paper examines the $\mathrm{MEH}$ as a particular case of public communication of science, a discipline defined as "the use of appropriate skills, media, activities, and dialogue to produce one or more of the following personal responses to science: awareness, enjoyment, interest, opinion-forming, and understanding" [Burns, O'Connor and Stocklmayer, 2003, p. 183]. As such, it is not possible to conceive science without considering its audience, context and the social reactions it triggers [Einsiedel, 2007].

However, the most significant challenge science communication currently has to face is incorporating the evaluation of results to check if the communication process was able to generate any changes in those involved [von Foerster, 1981], and thus establish its scope [Neresini and Pellegrini, 2008].

Science communication usually adopts mediated and non-mediated formats. As widely accepted, non-mediated formats include museology [Gregory and Miller, 1998; Turrent, 2001], which implies the exhibition of scientific content at facilities specially designed for such purpose. In this sense, when assuming that communication is the main objective of exhibitions [García Blanco, 1999], it is necessary to examine the means by which the visitors of a museum intertwine their experience with the cultural heritage, the stories and the various devices in a given space [Alonso Fernández and García Fernández, 1999; Hernández Hernández, 1998]. Therefore, a science exhibition can be defined as a form of communication [García Blanco, 1999] which acts as a mediator between visitors and the exhibits to facilitate their understanding [Shärer, 2000].

Today, the existing museums reflect different notions of what "being a museum" is. Such notions are connected to the historical development of each institution, and can range from the Cabinets of Wonder or Wunderkammer, dating back to the Renaissance, to temple-museums, in which knowledge and solemnity reign, and finally, to the most recent models, adapted to the new museology trends, which 
support the creation of spaces promoting encounters, interaction and recreation for all ages. The nineteenth-century temple-museum notion was more based on the superiority of knowledge or art. Hence, the contemplative and almost sacred concept of "please do not touch" implied the projection of a message which - to the audience - was both distant and inaccessible. However, the early $20^{\text {th }}$ century already saw the launch of a process that reconfigured museums - especially science museums - as recreational facilities [Chaparro, 2013; Friedman, 2010; Hernández Hernández, 1994; Schiele, 2008]. These institutions have been widely examined in the context of different models of science communication and popularization [Lewenstein and Allison-Bunnell, 2000; Durant, 2004; ICOM, 2013; Van Mensch, 2016; Cárdenas, 2017]. According to Lewenstein [2005], dissemination can be classified on the basis of two main models: the deficit model and the contextual model. In the former, the function of popularization is "bringing" positivist science knowledge and scientific thinking to an audience not familiar with it (this could be associated with more traditional and old-fashioned museums, such as temple museums). On the contrary, according to the contextual model - also called democratic model - people do have knowledge, interests, needs and a vision (whatever that is) of science, and communication implies taking this into account. In addition, there is a sociohistorical vision of science [Pacheco Muñoz, 2007, p. 185] and this would include, for example, those museums that survey their audiences not only in terms of appreciation but also understanding, and adopt an informative perspective that goes beyond the deficit or reductionist model [Chittenden, Farmelo and Lewenstein, 2004].

In this context, the studies on the perceptions of visitors in relation to the presentation of an archaeological site to an audience or a museum exhibition serve as a key instrument in the context of science communication and dissemination, and have been widely used internationally [Merriman, 1991; McManus, 2000]. These investigations aim to gain knowledge about the way visitors interpret the information provided [McManus, 2000]. Most of the studies on the museum and exhibition audiences are mainly designed to evaluate the exhibition, but also to learn about the knowledge and understanding of visitors [Pérez Santos, 2000; Murriello, 2006]. These efforts aim to analyze, evaluate, understand, record and interpret the characteristics, behaviours, motivations and cognitive and emotional aspects of museum visitors. Another aspect this type of analysis focuses on is the process of the visit, considering that in such experience an interrelation between the personal, sociocultural and physical dimensions of the audience is established [Vergo, 1989; Laumonier, 1993; Falk and Dierking, 1992]. Finally, it should be pointed out that these studies reveal the complexity of evaluating or measuring whether the visit produced knowledge, an issue that continues to be a subject of debate among educators and specialists to this day.

In the case of Spain, according to Pérez Santos [2008a] visitor profiling studies first originated in the 1980s with the earliest scientific works carried out by Carme Prats [1989], who established the first department of audience evaluation and studies at the National Museum of Natural Sciences of Madrid. Subsequently, at this institution numerous theoretical [Muñoz and Pérez Santos, 1990; Pérez Santos, 1995; Pérez Santos, 1995] and practical [Muñoz and Pérez Santos, 1991] works were developed. In the 1990s, several of such investigations were carried out at the National Archaeological Museum, extending this methodology to other institutions dedicated to various subjects. In the Spanish landscape, it can be generally 
observed that most of the studies on museum audiences have a descriptive nature with respect to the characteristics of visitors, and mainly focus on sociodemographic variables [Pérez Santos, 2008a]. Traditionally, this type of analysis was carried out to gain useful information for the management of museums. Only a few works made an attempt to compare audience studies. Similarly, another problem was the limited impact of the results obtained on management decisions [Pérez Santos, 2008a]. However, between 2008 and 2009, an analysis of all the museums managed by the General Directorate of Fine Arts was carried out in Spain, through the Permanent Laboratory of Museum Audiences, part of the Ministry of Culture [De Los Angeles et al., 2008; Laboratorio Permanente de Público de Museos, 2011]. The purpose was to improve each individual museum and promote management policies based "on and for the audience" [Pérez Santos and García Blanco, 2011, p. 15]. So far, this innovative initiative has made it possible to conduct further research on the audience of eleven museums dealing with various themes. Subsequently, the studies were compared to take a comprehensive picture of the situation of the museums that are part of the aforementioned organization.

Analysis of the case study
The work presented here provides insight not only on the profile of visitors to the $\mathrm{MEH}$, but also on their perceptions regarding the items exhibited, consistently with the objectives of public communication of science. In this case, in the process of valuation of the archaeological heritage, it serves as a pillar underpinning effective cultural transmission, capable of generating attitudes and guiding actions in relation to the meaning and the value that the audience gives to the archaeological heritage [Conforti, 2013]. According to Burns, O'Connor and Stocklmayer [2003] generating awareness on certain scientific knowledge is an inescapable exercise of reflection that in this case clearly contributes to the process of patrimonialization of cultural assets [Conforti and Mariano, 2013].

This analysis is an input that could be useful to the work of the museum managers and, at the same time, contribute ideas to academic debates about the importance of knowing the interpretation visitors give to heritage sites [ICOMOS, 2007].

This study focuses on two types of analysis, the sociodemographic aspect and the evaluation of MEH exhibits [Bitgood, 1996] and the approaches may be more or less in-depth, i.e. from exploratory, descriptive, descriptive-correlational to explanatory [Pérez Santos, 2008b]. In this sense, this work aims to investigate the processes of interaction between the characteristics of visitors and the exhibition context, so this can be classified as a descriptive-correlational study.

The survey form contained 25 questions with closed and open-ended questions, which aimed to investigate three different issues: on the one hand, the sociodemographic profile, and on the other, the visiting habits, interests, assessments, opinions of the audience and, finally, certain cognitive aspects (Figures 6 and 7). For the design of the questionnaire, the previous study carried out by the MEH was used as a reference, in order to differentiate specific aspects of the questions that refer to the interest of the researchers. This way, a mere description of the visitors could be avoided to also include aspects that put in 
relation the heritage of Atapuerca and its exhibition for the public. ${ }^{2}$ To carry out this study, an anonymous questionnaire was chosen for all the people over 18 who visited the permanent exhibition. The sampling was random and the protocol used was submitting the survey to the tenth visitor leaving the exhibition, with the form being filled out by the visitor in a non-guided way. In this way, 12 people were surveyed per shift each day (morning and afternoon) for twenty-five days. In general, a good predisposition to participate in the study was observed. The survey was conducted between February 15 and March 15, 2015, from Tuesday to Sunday.

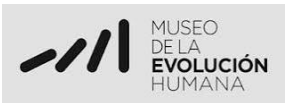

\section{VISITOR SURVEY \\ 2015 \\ PERMANENT EXHIBITION}

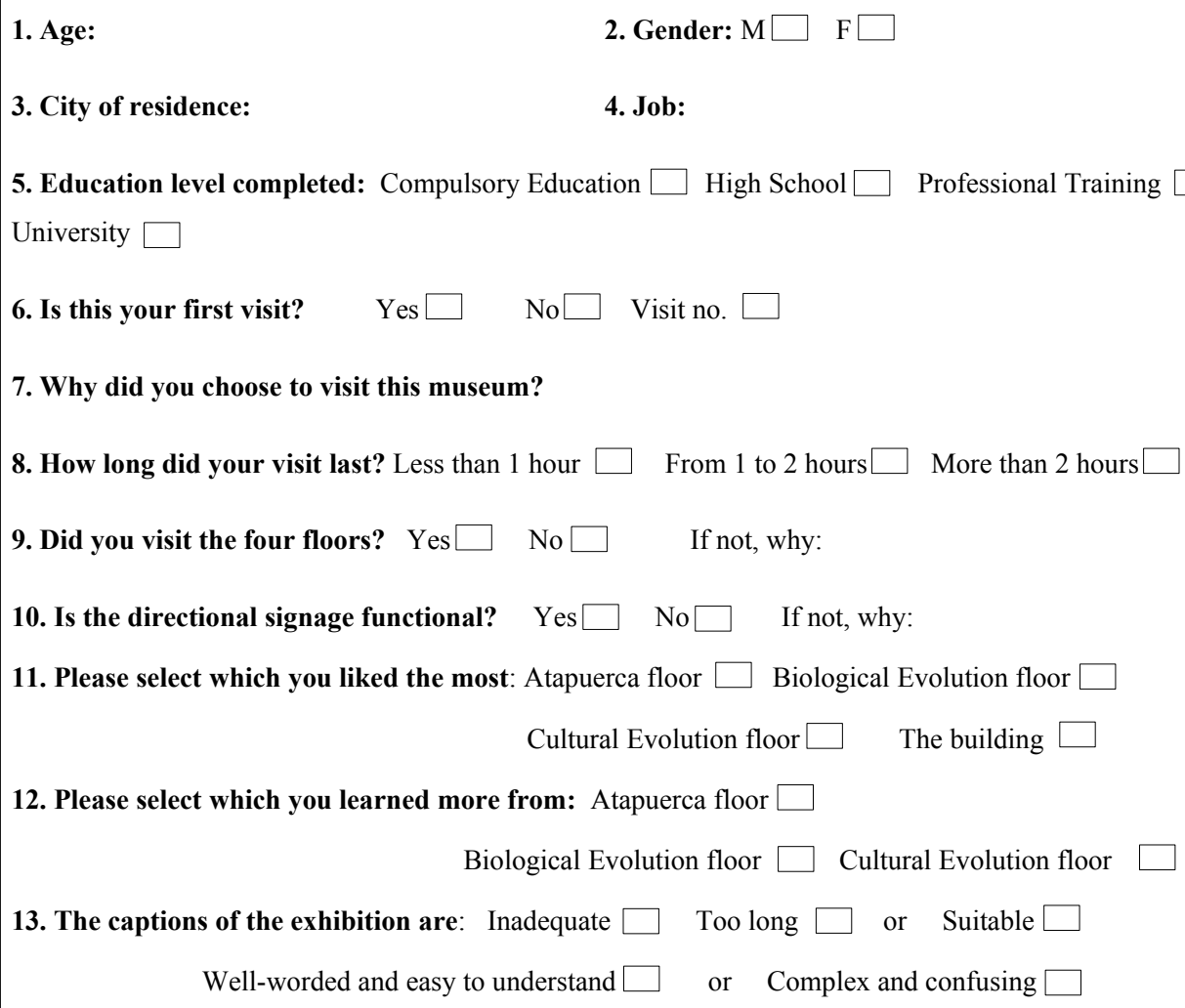

12. Please select which you learned more from: Atapuerca floor

$$
\text { Biological Evolution floor } \square \text { Cultural Evolution floor }
$$

13. The captions of the exhibition are: Inadequate $\square \quad$ Too long $\square \quad$ or $\quad$ Suitable

$$
\text { Well-worded and easy to understand } \square \text { or Complex and confusing }
$$

14. Which one did you like the most: Fossils and original pieces $\square$ Drawings and past reconstructions $\square$ Sculptures interpreting the past $\square \quad$ Informative videos $\square \quad$ Interactive resources

15. Which do you think was more important in human evolution?

$$
\text { Biological Evolution } \square \quad \text { Cultural Evolution } \square
$$

16. Which do you think will be more important for humans in the future?

Figure 6. Survey questionnaire. Page 1.

\footnotetext{
${ }^{2}$ The pilot survey (pre-test) was initially carried out applying with the same protocol to 20 visitors with the aim of checking possible drawbacks of language, length and overlap of information [Pérez Santos, 2000, p. 106]. The results were satisfactory so the script of the survey was not modified, and the results of this pre-test phase were included in the total sample $(\mathrm{N}=644)$.
} 
17. What do you associate this Museum with? Science $\square \quad$ Human Being $\square \quad$ Atapuerca $\square$
Past/Heritage $\square \quad$ Evolution $\square$

18. Please tell us something you've just learned that you didn't know before:

19. Please define this Museum in one word:

20. Why is Atapuerca important for human evolution?

21. Do you think we are primates and come from apes? Yes $\square$ No $\square$

22. How do you imagine the future for our species?

We will become extinct $\square \quad$ We will give rise to a new species

We will be the same in ten thousand years

23. What does Atapuerca mean to you? Heritage belonging to everyone which must be preserved

An interesting example of life in the past

An important discovery for science

24. When you saw the remains of our ancestors did you experience an emotional bon with them?

$$
\text { A lot } \square \quad \text { A little } \square \quad \text { Not at all } \square
$$

25. In your visit, was there anything you didn't like or you don't agree with?

Thank you for participating

The total number of surveys conducted was $644 .{ }^{3}$ Comparing this figure to the number of people who visited the MEH permanent exhibition over the period in which the study was conducted, it corresponds to an average of approximately $7 \%$ of the total visitors. This calculation was made considering a survey period going from mid-February to mid-March. Table 1 shows the number of visitors to the MEH permanent exhibition in February and March of the past five years, taking the implementation period of this study as a reference. What can be inferred from such data is that these visitor figures correspond to the "low season" months for the museum, since visits decrease in February and increase again in March with the arrival of good weather and spring in Spain.

\footnotetext{
${ }^{3}$ For uniformity, we opted not to use percentages in this "Findings" section, as they are not applicable to a few questions allowing for multiple answers. We used percentages in the discussion instead, as they allow us to establish comparisons easily.
} 
Table 1. Number of visitors to the MEH permanent exhibition in February and March from 2011 to 2015 (Source: MEH).

\begin{tabular}{|rrr|}
\hline Year & No. of visitors in February & No. of visitors in March \\
\hline 2011 & 13,472 & 18,076 \\
2012 & 5,945 & 12,841 \\
2013 & 6,045 & 15,465 \\
2014 & 6,702 & 9,538 \\
2015 & 6,395 & 11,845 \\
\hline
\end{tabular}

According to the findings in terms of sociodemographic profile, 380 visitors were males and 260 were females ( 4 respondents did not provide an answer); the age of the respondents widely ranged from 18 to 80 years, with those over 70 and under 20 being the least represented age groups (Table 2). The largest number of visitors (585) came from different regions of Spain, including 148 from the capital and 89 from the province of Burgos; only 35 respondents came from abroad. In relation to the education level, the majority of the respondents had a university education (344), followed by those who completed their professional training (140) and those who graduated from high school (93).

Table 2. Age of the respondents $(\mathrm{N}=644)$.

\begin{tabular}{|cr|}
\hline Age interval & Visitors \\
\hline $18-20$ & 33 \\
$21-30$ & 114 \\
$31-40$ & 107 \\
$41-50$ & 123 \\
$51-60$ & 101 \\
$61-70$ & 107 \\
$71-80$ & 16 \\
No answer & 43 \\
\hline
\end{tabular}

With regard to the visiting habits, it is worth noting that 535 respondents visited the $\mathrm{MEH}$ for the first time, while the remaining 109 had already seen it. In particular, 376 respondents devoted one to two hours to the visit, 236 took more than two hours and a minimal amount (27) said that they visited the exhibition in less than one hour (5 visitors did not provide an answer). An important aspect related to the issue of time is whether the visitors saw the permanent exhibition in its entirety: 577 said they visited it completely, while 65 could not do so. The reason that prevailed in the answers is the lack of time ( 25 answers).

These are the findings in relation to the questions that required some type of evaluation or expression of interests and opinions: the thing visitors liked the most about the MEH is the Atapuerca floor (328), followed by the biological evolution floor, then the building (83), and finally the cultural evolution floor (78). A few respondents selected all of the options (56), making it a multiple answer. Only 4 respondents did not provide an answer.

Answering the question on why they visited the MEH, the vast majority of visitors emphasized their interest and pleasure in learning about the subject (289). 
Secondly, as a reason for their visit, the respondents mentioned tourism and the reputation of the museum (85), thirdly a recommendation (60) and finally a follow-up to a visit to the archaeological sites (40) (Table 3). It should be noted that this was an open-ended question, and therefore the answers were grouped into categories devised by the researchers, based on the similarity of the answers. This approach was adopted with all the open-ended questions contained in the questionnaire.

Table 3. Reason for the visit $(\mathrm{N}=644)$.

\begin{tabular}{|lr|}
\hline Why did you choose to visit this museum? & Answers \\
\hline Interest and pleasure in learning about the subject & 289 \\
Tourism and reputation of the museum & 85 \\
Recommendation & 60 \\
Follow-up to a visit to Atapuerca & 40 \\
Representative of Burgos & 37 \\
Accompany someone & 25 \\
Other answers & 24 \\
No answer & 84 \\
\hline
\end{tabular}

On the other hand, a high number of visitors said that what they enjoyed the most was seeing fossils and original items (313), followed in decreasing order by the videos (130), the sculptures (123) (which are one-to-one scale representations of different species of hominids), and the drawings and reconstructions (103). A significant number of respondents said that they liked everything, marking all the four options, making this a multiple-choice question. The vast majority also said (620) that the museum itinerary is well marked with directional signage. In relation to the exhibition captions, the respondents said that are well worded and easy to understand (427) and suitable in terms of length (390).

Other aspects of the questionnaire involved the opinions of the respondents on what they believe was the most important thing in human evolution. Biological evolution ranked first in the answers (383), followed by cultural evolution (181). However, 68 respondents marked both options. On the same issue, but with a forward-looking approach, they were asked what they think would be more important for humans in the future. In this case, the percentages are inverted: most said cultural evolution (445), while 146 said biological evolution (45 chose both options). Also with the aim of surveying their predictions and the reflections on the subject that underlies their visit, respondents were asked about how they imagine the future of our species. The majority of them responded that we will give rise to a new species (274), secondly that we will become extinct (210), and finally that in about ten thousand years we will look the same (131).

When asked about what they associate the museum with, most respondents chose more than option, selecting Evolution in the first place (318), followed by Human Being (214), Atapuerca (182), Science (157) and Past/heritage (82). Answering the question "What does Atapuerca mean to you?" the majority responded "Heritage that belongs to all and we must protect" (428), followed in decreasing order by "An important discovery for science" (258) and "An interesting example of life in the past" (113). 
On the other hand, when asked to define the MEH with a single word, most of the respondents chose not to answer. The answers provided were so varied that they could hardly be grouped into categories. However, Table 4 below shows a summary of the results.

Table 4. How to define the MEH using one word $(\mathrm{N}=644)$.

\begin{tabular}{|lr|}
\hline Choose a word to define this Museum & Number \\
\hline No answer & 320 \\
Spectacular & 145 \\
Interesting and clear & 36 \\
Other mixed answers & 33 \\
Didactic & 27 \\
Wide and luminous & 24 \\
Innovative & 18 \\
Culture and science & 11 \\
Entertaining & 10 \\
Indispensable & 10 \\
Past & 6 \\
Evolution & 4 \\
\hline
\end{tabular}

Asked about whether they developed an emotional bond with the hominid ancestors, 277 respondents said "a little" and 263 said "a lot", meanwhile 82 said "not at all." Therefore, the majority of the respondents said they felt some type of emotional bond, to a greater or smaller extent. However, we consider this to be somewhat of an unclear aspect and a point to discuss further. Finally, when asked about whether in the museum there was something that they did not like or they did not agree with, the vast majority did not answer (296), while 252 said "Nothing." Among those who expressed some criticism, it is worth mentioning that some said that there is too much room for so little content, wayfinding is not effective and the museum is not equipped with enough recreation areas (Table 5).

Table 5. Criticism $(\mathrm{N}=644)$.

\begin{tabular}{|lr|}
\hline Considering your visit, is there anything you didn't like or you don't agree with? & Answers \\
\hline No answer & 296 \\
Nothing & 252 \\
Other mixed answers & 28 \\
Too much room for little content & 27 \\
Unclear itinerary directions & 17 \\
Lack of recreation areas and comforts (armchairs/chairs, soda machines, too hot inside, etc.) & 12 \\
Very long & 7 \\
Guided tours would be necessary & 5 \\
\hline
\end{tabular}

The final group of questions include those aimed at revealing cognitive elements. When directly asked on which floor they learned more information, the majority responded the Atapuerca floor (330), then the biological evolution floor (233), and lastly the cultural evolution floor (84). In addition, 25 people did not answer this question and 21 marked all the options, making it a multiple-answer question. On the other hand, when asked to mention something they did not know prior to their 
visit (open-ended question), the majority of respondents did not provide any answer (342). Among the topics mentioned by those who provided an answer there is biological evolution in the first place (138), followed by the Atapuerca sites in second place (93), and then by cultural evolution (35), research and archaeological methods (10). When asked why they think Atapuerca is important for human evolution, the majority of respondents said because of the original knowledge that it contributes to the theme (380) and then because of its large amount of remains and the value they possess (65). In addition, 191 respondents did not answer this open-ended question. Finally, when asked whether they think we are primates and come from apes, the vast majority of respondents gave a positive answer (536) and only 69 said we do not (39 did not respond at all).

Following we present the issues to be discussed in relation to the abovementioned findings.

With regard to the profile of the visitors, whereas their ages evidently cover all age groups, there appears to be a greater representation of men (59.4\%) (Figure 8). On the contrary, the survey conducted by the Museum between 2011 and 2012 showed a predominance of women over men, a trend that can also be found on a regional scale, for example at the National Museum of Altamira [Laboratorio Permanente de Público de Museos, 2011]. It is a museum that has many features in common with the $\mathrm{MEH}$, as it similarly hosts an archaeological exhibition on a nearby region which has a unique and exceptional value and is included in the UNESCO World Heritage list.

In terms of education level, the majority of visitors received higher education, which coincides with the general trend identified in Spain and in different European countries [Laboratorio Permanente de Público de Museos, 2011]. In the case of the MEH, another matter that could be related to the education level is the reason for the visit, as a high percentage of respondents expressed interest and pleasure in learning about the subject, which could be interpreted as intellectual motivation. In this regard, already in the 1960s Bourdieu and Darbel established a relation between the frequency of visits to museums and the level of education of visitors. Apparently, possessing a key to interpretation is something that allows visitor to appreciate the exhibition at best [Bourdieu and Darbel, 1969]. To address this issue, which could be associated with an elitist approach, museums practically pursue inclusive policies aiming to overcome the discrimination of other types of audience [Lussier-Desrochers, Lemerise and Lopes, 2003; Loram i Gilli, 2005]. The education level of visitors is an element which was previously overlooked (in the 2011-2012 general survey conducted by the MEH): if properly considered, it could provide a few insights to devise new strategies and attract visitors with only a basic education who do not normally attend the museum. Gender equality and age diversity could be other aspects to use in order to formulate new proposals aimed at specific groups, mainly in the periods of the year which report lower attendance levels.

The country of origin of the vast majority of visitors is Spain (90\%), specifically with a $23 \%$ share coming from the city of Madrid and a 13.8\% share from the province of Burgos, a trend that confirms the findings of the previous general survey. In particular, half of the visitors who had already seen the MEH in the past come from Burgos, which may suggest that it is a recurring destination for local 


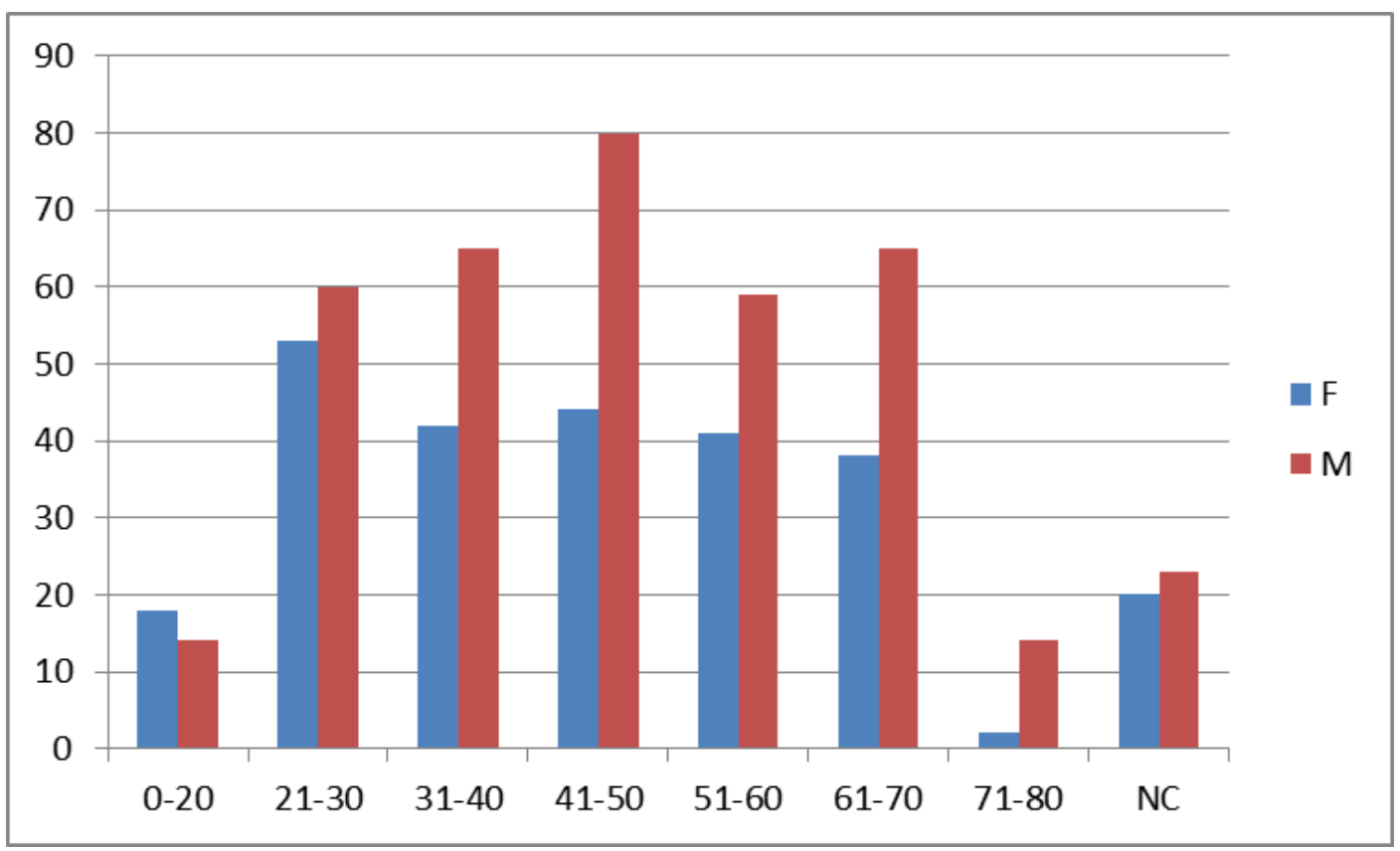

Figure 8. Graph showing the relation between gender and age groups.

people (Table 6) or that Burgos residents usually accompany non-residents (e.g. relatives and friends) to visit the museum. Another fact to consider when drawing a comparison with the previous survey is that the visitors returning to the museum increased from $11 \%$ to $17 \%$, perhaps owing to the years elapsed since its opening. All the information described above allows us to say that visitors usually plan their visit to the museum estimating the time slot required for their visit in advance.

Table 6. Origin of repeat visitors, based on the respondents to question 6: "This is not the first time we have visited the museum" $(\mathrm{N}=109)$.

\begin{tabular}{|lc|}
\hline Place of origin & Based on the answers to question 6 \\
\hline Burgos & $(61) 55 \%$ \\
Madrid & $(12) 11 \%$ \\
Other cities of Spain & $(37) 34 \%$ \\
\hline
\end{tabular}

A minimal percentage (3\%) of respondents complained about the extension of the exhibition in general. It should be noted that, differently from the previous survey, a small number of respondents pointed out the lack of amenities such as resting chairs, soda machines and complained about high indoor temperatures.

In terms of satisfaction, it should be highlighted that visitors have a positive opinion of the museum. A large majority thinks that the signage system is well-designed and the captions to the exhibition are suitable, easy to understand and clear. Visitors also said that they liked most of the museum exhibits, with the exhibition of fossils and original pieces being one of the main attractions. This could be partly related to the tendency that Moreno Guzmán [2001] described as the "enchantment" the visitors experience when they find themselves in a museum displaying original pieces. It should be clarified that, although this study did not explore the details of the visitors' opinion on each museum exhibit (as in the 
previous survey of 2011-2012), when given the opportunity of expressing disagreement, the surveyed visitors did not express any major dissatisfaction. This is a significant improvement in relation to the museum experience, as visitors had previously expressed criticism about these points, offering recommendations that the managers now appear to have adopted.

With regard to the visitors' perception of the relationship between the museum and the archaeo-paleontological sites - the second aspect to be discussed in this work - a few issues can be highlighted as follows. On the one hand, visitors still show a strong preference for the section devoted to the Atapuerca exhibition: they say it is the proposal they learned more from and, based on this, they give the sites a high value in terms of heritage and scientific content, which is the primary goal of the museum. An assumption that can be made on the basis of these answers is that visitors do not necessarily attend both spaces, the sites and the MEH, two proposals intended to be complementary in the framework of SACE.

Similarly, respondents acknowledge having learned something new about evolution, for example what links human beings with primates and apes. At the same time, they emphasize the importance of Atapuerca in this process and point out that the future will depend on the decisions that humanity will make at the cultural level, rather than on the biological evolution of the species.

It is worth nothing that this study is the first to publicly present a survey on the $\mathrm{MEH}$. This includes not only the sociodemographic profile, but also the satisfaction level of visitors and a few cognitive issues, aspects that were not considered in the studies carried out by the Laboratorio Permanente de Público de Museos (2011). Although the analysis presented here attempts to learn about these more complex aspects, the limitations of the methodology used should be acknowledged, as investigating satisfaction and cognitive issues requires a qualitative approach allowing for closer examination. However, the scope of this study - albeit at an exploratory and preliminary stage - makes it possible to introduce the subject in the social debate in Spain and/or Europe, mainly on the role that museums play as communication spaces, presenting globally relevant cases such as Atapuerca. In this context, a possible recommendation for the MEH would be to regularly schedule this type of studies and the publication of the findings thereof, so that specialists in the field can have access to them.

\section{Conclusions}

Thanks to this study, it is possible to say that the MEH fulfils its objective of connecting the sites with its exhibition, and succeeds in generating interest in the evolution and the role Atapuerca plays in it. The information the museum provides contributes to a greater understanding and awareness on its importance. Such results could be further improved by applying other techniques which provide information on how socially appropriate this scientific knowledge on the past is and how significant it becomes within so much cultural heritage. The archaeological heritage fundamentally becomes testimony of the past which allows us to materialize its existence, recall its memory and give meaning to its material traces [González Méndez, 2000]. Thus, its significance depends on knowledge and intellectual work, as well as on its public communication [Conforti, 2013]. 
In summary, the MEH exhibition represents an indispensable step in the path that has been linking archaeological research and the community in Atapuerca since the 1970s. In fact, it provides a permanent institutional response - which is more complete and intellectually more accessible than the site itself — presenting the field research and promoting wide dissemination as a public correlate of such research. In this context, visitor profiling becomes relevant: visitors contribute to consolidate this relation as they provide the element of evaluation in science communication practices, something which becomes more and more necessary in this field.

Acknowledgments

We would like to thank the authorities of the Museum of Human Evolution, the Universidad de Burgos and the Junta de Castilla y León for having promoted the implementation of this study. This work was funded by an Erasmus Mundus South-EU postdoctoral research grant implemented by author María Eugenia Conforti and developed at Instituto de Arqueología Prehistórica, Universidad de Burgos, Spain. It is also part of a research project carried out within the PATRIMONIA Program, Instituto de Investigaciones Arqueológicas y Paleontológicas del Cuaternario Pampeano (INCUAPA), Unidad Ejecutora del Consejo Nacional de Investigaciones Científicas y Técnicas (CONICET) and the Universidad Nacional del Centro de la Provincia de Buenos Aires (UNICEN), Argentina.

Translated by Massimo Caregnato

\section{References}

Alonso Alcalde, R. and Martín Nájera, A. (2013). 'Atapuerca y el Museo de la Evolución Humana. Historia de un modelo de difusión del patrimonio'. Treballs d'Arqueologia 19, pp. 27-40.

Alonso Fernández, L. and García Fernández, I. (1999). Diseño de exposiciones. Concepto, instalación y montaje. Madrid, Spain: Alianza editorial.

Arsuaga, J. and Martínez, I. (2001). La especie elegida. Madrid, Spain: Temas de Hoy.

Bitgood, S. (1996). 'An overview of visitor studies: what is it and what methods does it use?' Seminario Internacional. In: Museum Visitors Studies. Mérida, Spain.

Bourdieu, P. and Darbel, A. (1969). El amor al arte. Los museos europeos y su público. Spanish translation (2004). Buenos Aires, Argentina: Paidós.

Bucchi, M. and Trench, B., eds. (2008). Handbook of Public Communication of Science and Technology. London, U.K. and New York, U.S.A.: Routledge.

Burns, T. W., O'Connor, D. J. and Stocklmayer, S. M. (2003). 'Science Communication: A Contemporary Definition'. Public Understanding of Science 12 (2), pp. 183-202. https://doi.org/10.1177/09636625030122004.

Carbonell, E. and Sala, R. (2000). Planeta humano. Madrid, Spain: Península.

Cárdenas, B. (2017). 'New possibilities for science museums: Museological Reflections Group, 1st edition'. JCOM 16 (01), R02. https://doi.org/10.22323/2.16010602.

Chaparro, M. (2013). 'Acerca de los museos: su problemática actual, su historia y su vinculación con el patrimonio'. In: Temas de patrimonio cultural. Ed. by M. Endere, M. Chaparro and C. Mariano. E-Book. Tandil, Argentina: Universidad Nacional del Centro de la Provincia de Buenos Aires, pp. 51-70. 
Chittenden, D., Farmelo, G. and Lewenstein, B. V., eds. (2004). Creating Connections: Museums and the Public Understanding of Current Research. Lanham, MD, U.S.A.: AltaMira Press.

Comunidad de Castilla y León (2009). Decreto creación del sistema Atapuerca, cultura de la evolución y el museo de la evolución humana. Burgos, Spain.

Conforti, M. (2013). 'La comunicación pública de la ciencia y su importancia en la valoración del patrimonio arqueológico'. In: Temas de patrimonio cultural. Ed. by M. Endere, M. Chaparro and C. Mariano. E-Book. Tandil, Argentina:

Universidad Nacional del Centro de la Provincia de Buenos Aires, pp. 35-49.

Conforti, M. and Mariano, C. (2013). 'Comunicar y gestionar el patrimonio arqueológico'. Arqueología 19 (2), pp. 347-362. URL: http://hdl . handle.net/11336/29325.

Conforti, M., Díez Fernández-Lomana, J. C., Mariano, M. and Endere, M. (2017a). 'Patrimonio mundial y comunidad local. Visiones encontradas sobre Atapuerca'. Manuscrito.

Conforti, M. E., Díez Fernández-Lomana, J. C., Mariano, M., Endere, M. L. and Romero Alonso, A. J. (2015). 'World Heritage and the local community: the case of Atapuerca (Burgos, Spain)'. Conservation and Management of Archaeological Sites 17 (4), pp. 327-339. https://doi.org/10.1080/13505033.2016.1175904.

Conforti, M. E., Chaparro, M. G., Mariano, M. and Díez Fernández-Lomana, J. C. (2017b). 'Haciéndonos humanos. Análisis de una exhibición científica en Argentina'. Chungará. Revista de Antropología Chilena 49 (1), pp. 81-98. https://doi.org/10.4067/s0717-73562016005000038.

De Los Angeles, M., Canela, M., García Blanco, A. and Polo, A. (2008). ‘Los estudios de público, un instrumento de trabajo: la gestación de un proyecto'. Revista Mus-A 10, pp. 31-35.

Díez Fernández-Lomana, J. C., Navazo Ruiz, M., Alonzo Alcalde, R. and Pérez Moral, M. (2011). Guía gráfica de Atapuerca. Burgos, Spain: Ediciones de Diario de los yacimientos de la Sierra de Atapuerca.

Durant, J. (2004). 'The Challenge and the opportunity of presenting "Unfinished science"'. In: Creating Connections: Museums and the Public Understanding of Current Research. Ed. by D. Chittenden, G. Farmelo and B. V. Lewenstein. Lanham, MD, U.S.A.: AltaMira Press, pp. 47-60.

Einsiedel, E. (2007). 'Editorial: of publics and science'. Public Understanding of Science 16 (1), pp. 5-6. https: //doi .org/10.1177/0963662506071289.

Falk, J. H. and Dierking, L. D. (1992). The museum experience. Washington, D.C., U.S.A.: Whalesback Books.

Friedman, A. J. (2010). 'The evolution of the science museum'. Physics Today 63 (10), pp. 45-51. https://doi .org/10.1063/1.3502548.

García Blanco, A. (1999). La exposición como medio de comunicación. Madrid, Spain: Akal.

González Méndez, M. (2000). La revalorización del patrimonio arqueológico. La definición de un programa para el ayuntamiento de Toques (A. Coruña). Spain: Xunta de Galicia. URL: http://hdl. handle .net/10261/28269.

Gregory, J. and Miller, S. (1998). Science in public: communication, culture, and credibility. London, U.K. and New York, U.S.A.: Plenum.

Hernández Hernández, F. (1994). Manual de museología. Madrid, Spain: Síntesis.

- (1998). El museo como espacio de comunicación. Madrid, Spain: Trea.

ICOM (2013). Code of Ethics for Museums. Paris, France: ICOM. 
ICOMOS (2007). Carta ICOMOS de ENAME para la interpretación de lugares pertenecientes al patrimonio cultural. Comité Científico Internacional de Interpretación y Presentación de Sitios de Patrimonio Cultural. Paris, France: UNESCO.

Laboratorio Permanente de Público de Museos (2011). Conociendo a nuestros visitantes. Estudio de público en los museos del Ministerio de Cultura. Madrid, Spain.

Laumonier, I. (1993). Museo y sociedad. Los fundamentos de las ciencias del hombre. Buenos Aires, Argentina: Centro Editor de América Latina.

Lewenstein, B. (2003). 'Models of public communication of science and technology'. Manuscrito sin publicar.

Lewenstein, B. V. and Allison-Bunnell, S. (2000). 'Creating knowledge in science museums: serving both public and scientific communities'. In: Science centers for this century. Ed. by B. Schiele and E. Koster. Sainte-Foy, France: MultiMondes, pp. 187-208.

Lewenstein, B. V. (2005). 'Introduction - Nanotechnology and the Public'. Science Communication 27 (2), pp. 169-174. https://doi.org/10.1177/1075547005281532.

Loram i Gilli, M. (2005). 'Desenvolupament de públics: revisió bibliogràfica'. Zona Pública 1, pp. 1-13.

Lussier-Desrochers, D., Lemerise, T. and Lopes, I. (2003). ‘Le groupe focus et le questionnaire: deux méthodes complémentaires d'investigation des points de vue des adolescents sur les musées'. In: Le musée à la rencontre de sesvisiteurs. The museum reaching out to its visitors. Ed. by A. Landry. Sainte-Foy, QC, Canada: Les Éditions MultiMondes, pp. 215-228.

McManus, P. (2000). Archaeological display and the public. Museology and interpretation. London, U.K.: Archetype Publications.

Merriman, N. (1991). Beyond the glass case: the past, the heritage and the public in Britain. Leicester, U.K.: Leicester Press.

Moreno Guzmán, M. (2001). Encanto y desencanto. El público ante las reproducciones en los museos. México DF, Mexico: Obra diversa.

Muñoz, M. and Pérez Santos, E. (1990). 'Proceso de evaluación de exposiciones: una perspectiva psicológica'. In: II Encuentro I.C.O.M. (Pamplona, Spain).

- (1991). 'Comparación de la eficacia de distintos métodos expositivos en distintas exposiciones'. In: Psicología ambiental: intervención y evaluación del entorno. (Sevilla, Spain).

Murriello, S. (2006). 'As exibições e seus públicos: a paleontologia no museu de La Plata'. Tesis de Doctorado. Brasil: Universidade Estadual de Campinas.

Museo de la Evolución Humana (2013). Análisis de las encuestas de satisfacción de los visitantes. Museo de la Evolución Humana 2011-2012. Manuscrito sin publicar. Burgos, Spain: Museo de la Evolución Humana.

Neresini, F. and Pellegrini, G. (2008). 'Evaluating public communication of science and technology'. In: Handbook of Public Communication of Science and Technology. Ed. by M. Bucchi and B. Trench. London, U.K. and New York, U.S.A.: Routledge, pp. 237-251.

Ortega Azabache, M. (2016). ‘Impacto socioeconómico de los yacimientos de Atapuerca en Burgos'. Tesis de Grado. Burgos, Spain: Universidad de Burgos.

Pacheco Muñoz, M. (2007). 'Los museos de ciencia y la divulgación'. Redes 12 (25), pp. 181-200.

Pérez Santos, E. (1995). ‘El impacto de las exposiciones del Museo Nacional de Ciencias Naturales: 5 años de investigación sobre público'. Revista de Museología 5, pp. 43-52. 
Pérez Santos, E. (1995). 'El otro lado de las exposiciones científicas'. Carpeta del C.E.N.E.A.M. 7.

Pérez Santos, E. (2000). Estudios de visitantes en museos. Metodología y aplicaciones. Spain: Trea.

Pérez Santos, E. (2008a). ‘El estado de la cuestión de los estudios de público en España'. Revista Mus-A 10, pp. 20-30.

Pérez Santos, E. (2008b). 'Metodología básica de la investigación de público en museos: áreas de actuación, variables implicadas, tipos de investigaciones y técnicas utilizadas'. Revista Mus-A 10, pp. 58-71.

Pérez Santos, E. and García Blanco, A. (2011). ‘Presentación de la investigación'. In: Laboratorio permanente de público de museos 2011: informe general. Conociendo a nuestros visitantes. Estudio de públicos en Museos del Ministerio de Cultura. Ed. by Secretaría de Estado de Cultura. Spain: Subsecretaría General de Museos Estatales, pp. 14-15.

Prats, C. (1989). 'Anàlisi de l'impacte d'une exposició d'ecología i estudi experimental del seu efecte en l'adquisició de coneixements'. Tesis Doctoral. Barcelona, Spain: Universitat de Barcelona.

Schiele, B. (2008). 'Science museums and science centres'. In: Handbook of Public Communication of Science and Technology. Ed. by M. Bucchi and B. Trench. London, U.K. and New York, U.S.A.: Routledge, pp. 27-39.

Shärer, M. (2000). Le musée et l'exposition: variation de langages, variation de signes. Paris, France: ICOM.

Turrent, L. (2001). 'Arqueología y museos: un origen compartido'. Arqueología Mexicana 8 (47), pp. 82-85.

Van Mensch, P. (2016). 'Towards museums of the new century'. Museum International 22, pp. 15-18.

Vergo, P. (1989). The new museology. Wiltshire, U.K.: Reaktion Books.

von Foerster, H. (1981). Observing systems: selected papers of Heinz von Foerster. Seaside, CA, U.S.A.: Inter Systems Publications.

María Eugenia Conforti holds a degree in social communication and a $\mathrm{PhD}$ in social and human sciences. She is a researcher at the Consejo Nacional de Investigaciones Científicas y Técnicas (CONICET-ARGENTINA), in the framework of the Programa Interdisciplinario de Estudios del Patrimonio PATRIMONIA, Instituto de Investigaciones Arqueológicas y Paleontológicas del Cuaternario Pampeano INCUAPA (Implementing Unit of CONICET). Currently, she is the Academic Coordinator of the Higher University Diploma in Public Communication of Science, Faculty of Social Sciences, Universidad Nacional del Centro de la Provincia de Buenos Aires, Argentina. Her research focuses mainly on the themes of public communication of archaeology and archaeological heritage. ORCID 0000-0003-4261-0272. E-mail: mariaeugeniaconforti@gmail.com. E-mail: meconfor@soc.unicen.edu.ar.

María Gabriela Chaparro is a professor and graduate in anthropological sciences, with a PhD in archaeology. She works as a researcher at the Consejo Nacional de Investigaciones Científicas y Técnicas (CONICET-ARGENTINA), in the framework of the Programa Interdisciplinario de Estudios del Patrimonio PATRIMONIA, Instituto de Investigaciones Arqueológicas y Paleontológicas del Cuaternario 
Pampeano INCUAPA (Implementing Unit of CONICET). She is a lecturer at the Faculty of Social Sciences, Universidad Nacional del Centro de la Provincia de Buenos Aires, Argentina. Her research focus is on public archaeology, museums and cultural heritage. ORCID 0000-0003-3785-2912.

E-mail: chaparro@soc.unicn.edu.ar.

Pamela Degele holds a degree in anthropology with a specialization in archaeology. She is currently a doctoral fellow at the Consejo Nacional de Investigaciones Científicas y Técnicas (CONICET-ARGENTINA), in the framework of the Programa Interdisciplinario de Estudios del Patrimonio PATRIMONIA, Instituto de Investigaciones Arqueológicas y Paleontológicas del Cuaternario Pampeano INCUAPA (Implementing Unit of CONICET). Faculty of Social Sciences, Universidad Nacional del Centro de la Provincia de Buenos Aires, Argentina. Her research interests concern the fields of public archaeology, protected areas and territorial planning. E-mail: pameladegele@gmail.com.

Juan Carlos Díez Fernández-Lomana is an archaeologist, $\mathrm{PhD}$ in prehistory. $\mathrm{He}$ works as a Director of the Laboratorio de Prehistoria y Catedrático of the Universidad de Burgos. Burgos, Spain. His research covers areas such as taphonomy and zooarchaeology, in addition to the popularization of archaeo-paleontological heritage. E-mail: clomana@ubu.es.

How to cite

Conforti, M. E., Chaparro, M. G., Degele, P. and Díez Fernández Lomana, J. C. (2018). 'Visitor profiling at the Museum of Human Evolution of Burgos (Spain)'. JCOM 17 (04), A03_en. https://doi.org/10.22323/2.17040203. 